\title{
EVALUATION OF JUICE POMEGRANATE WASTES AS ORGANIC AMENDMENTS FOR SANDY SOILS
}

\author{
Salah A. E. Elcossy \\ Soil Conservation Dept., Desert Research Center, Cairo, Egypt
}

Key Words: juice pomegranate wastes, farmyard manure, soil chemical, physical properties, south of EL-Qantara East.

\section{ABSTRACT}

A field experiment was conducted at a sandy soil in south of ELQantara East station, North Sinai, to investigate the effect of applying juice pomegranate wastes (JPW) and farmyard manure (FYM) at the rates of $0,25,50,100$, and $150 \mathrm{Mg}^{-h^{-1}}$ on soil properties and yield of wheat. Soil $\mathrm{pH}$, and $\mathrm{EC}$ decreased with increasing the application rate of either JPW or FYM, while, the organic carbon content was increased. Also, soil bulk density, penetration resistance, and hydraulic conductivity were decreased with increasing application rates of either JPW or FYM. The maximum water holding capacity was increased. Grain wheat yield increased with increasing either JPW or FYM rates up to the $150 \mathrm{Mg}$.ha ${ }^{1}$. Obtained data showed that $\mathrm{N}, \mathrm{P}$ and $\mathrm{K}$ contents in grain wheat increased with increasing either JPW or FYM rate up to the $150 \mathrm{Mg}^{-h^{-1}}$. It could be concluded that either juice pomegranate wastes or FYM are a good source of $\mathrm{P}$ and $\mathrm{K}$ when applied to soil and its application may be reduce the amount of fertilizers required for optimum crop yield. The average yields were 2.91, 3.68, 4.77, and 5.74 Mg.ha ${ }^{-1}$ for JPW addition rates of $25,50,100$, and $150 \mathrm{Mg}^{-h a^{-1}}$, respectively. While, they reached

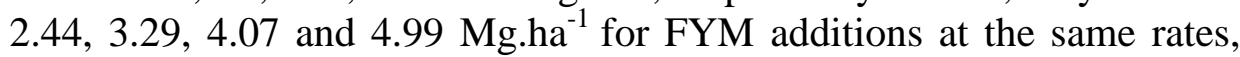
respectively. Statistical analysis showed that a quadratic function fitted the relationships between both JPW or FYM rates and grain wheat yield $\left(\mathrm{r}=0.99^{* *}\right.$ and $0.98^{* *}$, respectively). Differential's method of quadratic equation obtained was used to find the predicted values of critical level of rate JPW and FYM amendments, the value for critical level of rate

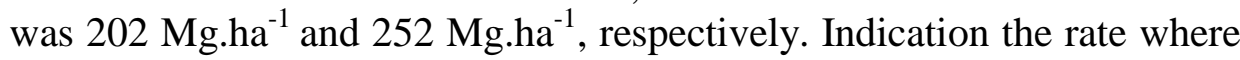
further change in the yield results in a reduction.

\section{INTRODUCTION}

Wheat is one of the most important and strategically crops in Egypt, but its area produced only about $30 \%$ of the domestic needs. There are several ways for increasing wheat production; one is the appropriate application of organic residues, especially in the newly 
reclaimed areas. Most of the newly reclaimed areas in the deserts of Egypt are sandy, with problems in their cultivation. Science they are very poor in their organic and their fertility. Organic materials such as crop residues and farmyard manure are available in abundance. Organic manures are commonly applied to the soil to improve their physical, chemical and biological properties (Yassen et al, 2010).

Jariwala and Syed (2016) reported that fruit peels are good source of nutrients they contain different antioxidants and carbonaceous matter, as in case of sulphate of ammonia; or they may be processed from quarries, they are cheape and harmless. Fruit peels such as pomegranate, orange, sweet lime and banana were utilization of fruit peels for the effective growth of plants and higher yield.

Divina, (2016) reported that fruit wastes can be used as by promoting its growth and development by enhancing soil fertility and enriching soil microbiota, and protecting them from insects, nematodes, fungi and other plant pathogens.

Pomegranate seeds are composed of nearly $27.2 \%$ fat, $13.2 \%$ protein, $35.2 \%$ crude fibers, $2 \%$ ash, $6 \%$ pectin, and $4.7 \%$ sugars (Adulse and Patil, 1995). They contain fatty acids, vitamins, polyphenols and proteolytic enzymes. (Dumlu and Gurkan, 2007). They also, contain $21 \%$ oil and $15 \%$ protein. (Golukci, 2014).

Under Egyptain condition, Abdel-Salam et al, (2018) studied 4 Egyptian pomegranate cultivars (Edkawy, Manfaloty, Sahrawy and Wonderful) and their juice extraction method ( pressing halves of fruits and blending separated arils) on characteristics and utilization of juice extraction wastes. The results showed significant variations in wastes yield and their content of bioactive compounds. Also, juice extraction and drying processes (were studied ). Generally, Edkawy cultivar gave higher yield of waste rich in bioactive compounds, antioxidant activity and reducing power. Nine simple phenolic acids were identified and quantified in Wonderful aril juice vacuum dried waste (gallic, ellagicchyrsin, protochatechuic, caffeic, ferulic, cinnamic, vanilic and syngic acids). This waste was also rich in dietary fiber at level of 58\% total dietary fibers.

Hasnaoui et al, (2014) Show that the processing one ton of pomegranate fruits yields approximately from 322 to 341 liters of juice and generates about $669 \mathrm{~kg}$ of pomegranate by-products made of pith, rinds, and peels. In fresh weight, the peel and internal membranes of the pomegranate represents $50 \%$. 
The main objective of this work was to study the effect of pomegranate juice wastes as organic amendments on some chemical and physical properties of sandy soil and evaluates their effects on wheat yield.

\section{MATERIAL AND METHODS}

The experiment was conducted in a sandy soil at south of ELQantara East station, North Sinai, between $\left(30^{\circ} 47^{\prime} 24^{\prime \prime}\right.$ and $30^{\circ} 52^{\prime} 12^{\prime \prime} \mathrm{N}$ latitude) and ( $32^{\circ} 17^{\prime} 24^{\prime \prime}$ and $32^{\circ} 24^{\prime} 36^{\prime \prime}$ E longitude). Soil analysis of the site and analysis of the used amendments i.e juice pomegranate wastes (JPW) and farmyard manure (FYM) are given in Table 1.

The juice pomegranate wastes were obtained from a factory in $10^{\text {th }}$ Ramadan City, Egypt.

Table 1: Chemical and physical characteristics of the studied soil and the amendments used.

\begin{tabular}{|c|c|c|c|c|c|c|c|c|c|c|}
\hline & \multirow[b]{2}{*}{ pH } & \multirow[b]{2}{*}{$\begin{array}{c}\mathrm{EC}_{\mathrm{e}} \\
\mathrm{dS} \mathrm{\textrm {m } ^ { - 1 }}\end{array}$} & \multirow[b]{2}{*}{$\begin{array}{c}\mathrm{OC} \\
\mathrm{g} \mathrm{kg}^{-1}\end{array}$} & \multirow[b]{2}{*}{$\begin{array}{c}\text { Bulk } \\
\text { Density } \\
\mathbf{M g ~ m}^{-3}\end{array}$} & \multirow[b]{2}{*}{$\begin{array}{c}\mathrm{CaCO}_{3} \\
\mathrm{~g} \mathrm{~kg}^{-1}\end{array}$} & \multicolumn{5}{|c|}{ Particle size distribution } \\
\hline & & & & & & $\begin{array}{c}\text { Fine } \\
\text { sand } \\
\%\end{array}$ & $\begin{array}{c}\text { Coarse } \\
\text { Sand } \\
\%\end{array}$ & $\begin{array}{r}\text { Silt } \\
\%\end{array}$ & $\begin{array}{c}\text { Clay } \\
\%\end{array}$ & $\begin{array}{c}\text { Texture } \\
\text { class }\end{array}$ \\
\hline $\begin{array}{l}\text { Soil depth } \\
(0-20 \mathrm{~cm})\end{array}$ & 7.98 & 7.56 & 1.97 & 1.66 & 12.0 & 45.28 & 46.72 & 4.8 & 3.2 & sand \\
\hline JPW & 6.37 & 1.17 & 274 & 0.87 & 4.0 & & & & & \\
\hline FYM & 7.1 & 2.15 & 230 & 0.98 & 9.3 & & & & & \\
\hline \multicolumn{11}{|c|}{ Total content of some elements of amendments used } \\
\hline & $\begin{array}{c}\mathrm{N} \\
\mathrm{g} \mathrm{kg}^{-1} \\
\end{array}$ & \multicolumn{2}{|c|}{$\begin{array}{c}\mathbf{P} \\
\mathrm{mg} \mathrm{kg}^{-1}\end{array}$} & $\begin{array}{c}\mathrm{K} \\
\mathrm{mg} \mathrm{kg}^{-1}\end{array}$ & $\begin{array}{c}\text { Fe } \\
\text { mg kg }^{-1} \\
\end{array}$ & $\begin{array}{c}\mathrm{Mn} \\
\mathrm{mg} \mathrm{kg}^{-1} \\
\end{array}$ & \multicolumn{2}{|c|}{$\begin{array}{c}\mathrm{Zn} \\
\mathrm{mg} \mathrm{kg}^{-1}\end{array}$} & \multicolumn{2}{|c|}{$\begin{array}{c}\mathrm{Cu} \\
\mathrm{mg} \mathrm{kg}^{-1} \\
\end{array}$} \\
\hline JPW & 16.11 & \multicolumn{2}{|c|}{15.33} & 18.56 & 250 & 90 & \multicolumn{2}{|c|}{38} & \multicolumn{2}{|c|}{2} \\
\hline FYM & 12.71 & \multicolumn{2}{|c|}{13.98} & 16.38 & 100 & 20 & \multicolumn{2}{|c|}{12} & \multicolumn{2}{|c|}{1} \\
\hline
\end{tabular}

pH in soil suspension and EC in soil paste extract

The experimental design was randomized complete block, with 5 replicates. Two amendments either juice pomegranate wastes or FYM at rates of $0,25,50,100$, and $150 \mathrm{Mg} \mathrm{ha}^{-1}$. The JPW and FYM were incorporated with surface soil layer $(0-10 \mathrm{~cm})$.

Wheat grains (Triticum a esitivum L.) c.v Giza 93 were sown on November $22^{\text {th }}$ in 2018/2019 season; at the rate of $144 \mathrm{~kg} \mathrm{ha}^{-1}$ by hand drilling in rows. The recommended rates of $\mathrm{N}, \mathrm{P}$ and $\mathrm{K}$ were applied for all plots; also the cultivation practices were followed as the recommendation of Ministry of agriculture and land reclamation. Also, all plots were received $50 \mathrm{~L} \mathrm{ha}^{-1}$ effective microorganisms (EM).

Wheat was harvested in late June. Whole plants were taken at harvest from each plot to determine grain yield. Samples of grain wheat 
were selected, at random, from each plot to determine $\mathrm{N}, \mathrm{P}$ and $\mathrm{K}$ concentrations.

Grain samples were dried and ground to pass a $0.5 \mathrm{~mm}$ stainless steel screen. Nitrogen was determined on $0.5 \mathrm{~g}$ subsamples by the macro- Kjeldahl methods (Phillips, et al., 1980). Concentrations were determined on an oven dry basis.

Potassium was determined in plant digest using flame photometer as described by Jackson (1973). Phosphorus was assayed in plant digest using ascorbic acid method described by (Fire, et al., 1964).

Undisturbed soil sample from each plot was taken from $0-20 \mathrm{~cm}$ depth to determine some soil properties.

Soil bulk density (BD) was determined using core as described by Blake (1986). Penetration resistance (Pn), was determined using penetrometer used. Pn measurements were repeated six times in each plot from locations baside BD measurements (ASAE, 1993). Hydraulic conductivity (HC) was determined according to Klute (1986). Maximum water holding capacity (MWHC) was determined according to (Stolte et al. 1992).

The soil water extract components were determined in the soil paste extract, and the following determinations were carried out by using the standard methods of analysis according to Jackson (1973). The total soluble salts were determined using EC mater. Soil reaction $(\mathrm{pH})$ was determined in the soil paste, according to Richards (1954). Organic matter was determined by the modified Walkley and Black method, (Jackson 1973).

\section{RESULTS AND DISCUSSION}

Chemical and physical properties of the studied soil as affected by JPW and FYM are presented in Table 2.

Table 2: Effect of juice pomegranate wastes (JPW) and FYM rates on some soil properties.

\begin{tabular}{|c|c|c|c|c|}
\hline treatments & $\begin{array}{c}\text { Rate } \\
\left(\mathrm{Mg} \mathrm{ha}^{-1}\right)\end{array}$ & pH & $\begin{array}{c}E C \\
d_{S} ~ m^{-1}\end{array}$ & $\underset{\left(\mathrm{g} \mathrm{kg}^{-1}\right)}{\mathrm{O.C}}$ \\
\hline Control & $\mathbf{0}$ & 7.98 & 7.56 & 1.97 \\
\hline \multirow{4}{*}{ 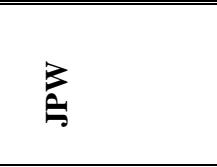 } & 25 & 7.89 & 6.91 & 2.74 \\
\hline & 50 & 7.86 & 6.23 & 3.53 \\
\hline & 100 & 7.82 & 5.71 & 4.01 \\
\hline & 150 & 7.74 & 4.93 & 4.97 \\
\hline \multirow{4}{*}{$\sum_{i}$} & 25 & 7.95 & 7.05 & 2.31 \\
\hline & 50 & 7.91 & 6.47 & 2.96 \\
\hline & 100 & 7.84 & 5.93 & 3.25 \\
\hline & 150 & 7.76 & 5.13 & 4.23 \\
\hline \multicolumn{2}{|l|}{$L S D_{(0.05)}$} & 0.017 & 0.093 & 0.145 \\
\hline
\end{tabular}




\section{Soil Chemical Properties: Soil pH:}

The juice pomegranate wastes (JPW) and the FYM had an acid and neutral reaction, respectively (Table 1). Table 2 and Fig. 1 shows that Soil $\mathrm{pH}$ decrease from 7.98 to 7.74 for JPW and from 7.98 to 7.76 for FYM, respectively, compared to the control. This effect may be attributed to the production of organic acids, $\mathrm{CO}_{2}$ and hydrogen ions $\left(\mathrm{H}^{+}\right)$. These results are in agreement with those obtained by Bulluck, et al, (2002). Abou Yuossef et al, (2007) found that the $\mathrm{pH}$ values decreased with applying organic manures. Also, Abdel-Aal (2015) found that FYM decreased bulk density, EC, $\mathrm{pH}$ and soil ESP and increased total porosity, hydraulic conductivity and soil organic matter.

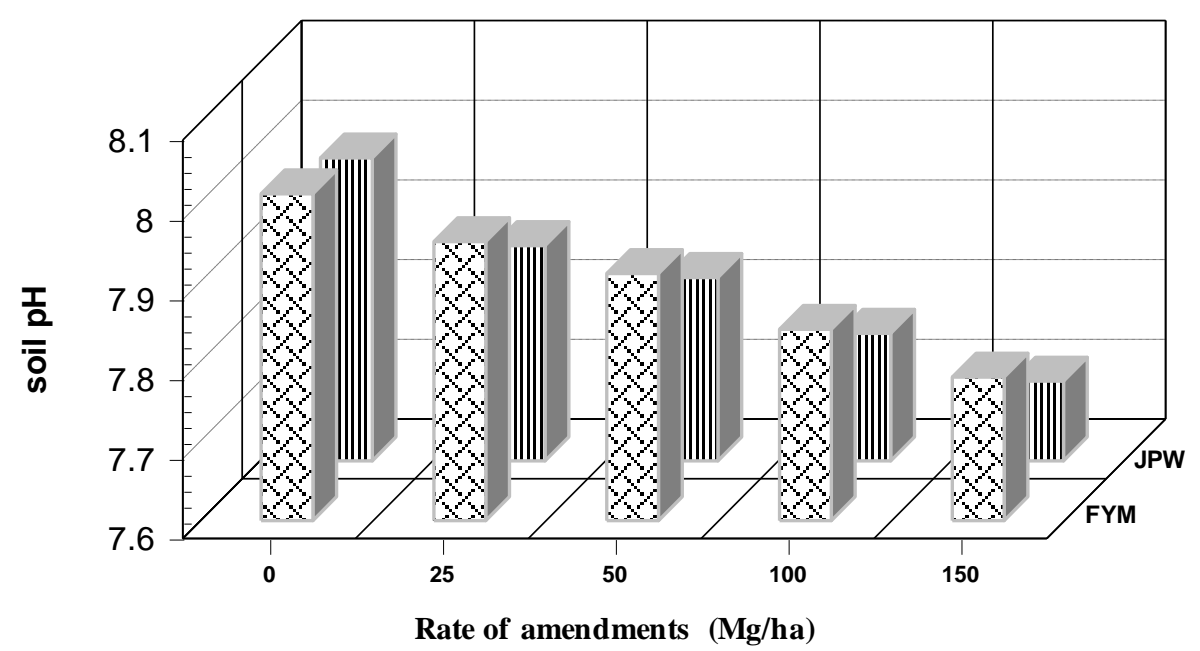

Fig. 1 Effect of JPW and FYM on soil pH

\section{EC of saturated soil extract:}

Effect of JPW and FYM rates on EC of the soil is shown in Fig. 2. The soil EC decreased from $7.56 \mathrm{dS} \mathrm{m}^{-1}$ to $4.93 \mathrm{dS} \mathrm{m}^{-1}$ for JPW and from $7.56 \mathrm{dS} \mathrm{m}^{-1}$ to $5.13 \mathrm{dS} \mathrm{m}^{-1}$ for FYM, respectively. The soil EC values were decreased with increasing the applied rates JPW and FYM, compared to the control.

The rate of decrement in EC values below the control reached 9, 18,24 and $35 \%$ due to treating the soil with JPW at the rates of 25, 50, 100 and $150{\mathrm{Mg} . h a^{-1}}^{-}$, respectively, while the respective decrement below the control reached 7, 14, 22 and 32\% due to FYM application rates (Table 2). The positive effect of JPW and FYM in decreasing the soil salinity may be due to their effect in increasing the ability of the soil to 
hold water (as was found in this study (Table 3). Therefore, more soluble salts will have the chance to be leached out by following irrigation.

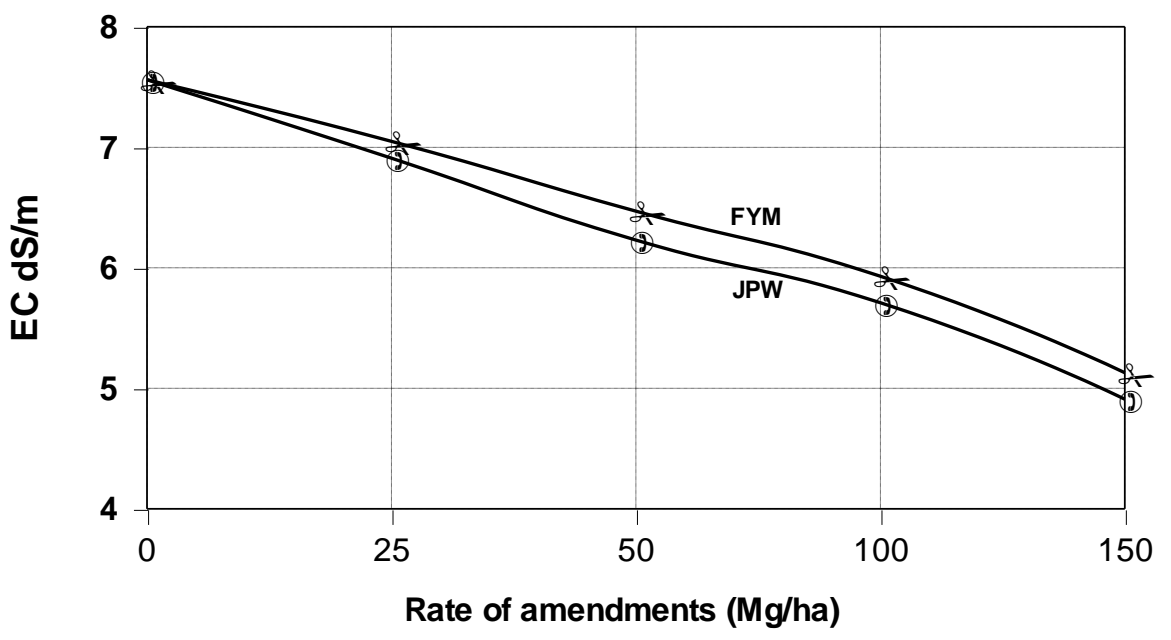

Fig. 2 Effect of JPW and FYM rates on soil EC

\section{Soil organic carbon (OC)}

Data in Table 2 and Fig. 3 show that the soil O.C increased as JPW or FYM rate increased. The rate of increment reached $28,44,51$, and $60 \%$ for JPW and 15, 33, 39 and 53\% for FYM due to the increase in JPW and FYM rates from 0 to $25,50,100$ and $150 \mathrm{Mg} \mathrm{ha}^{-1}$, respectively

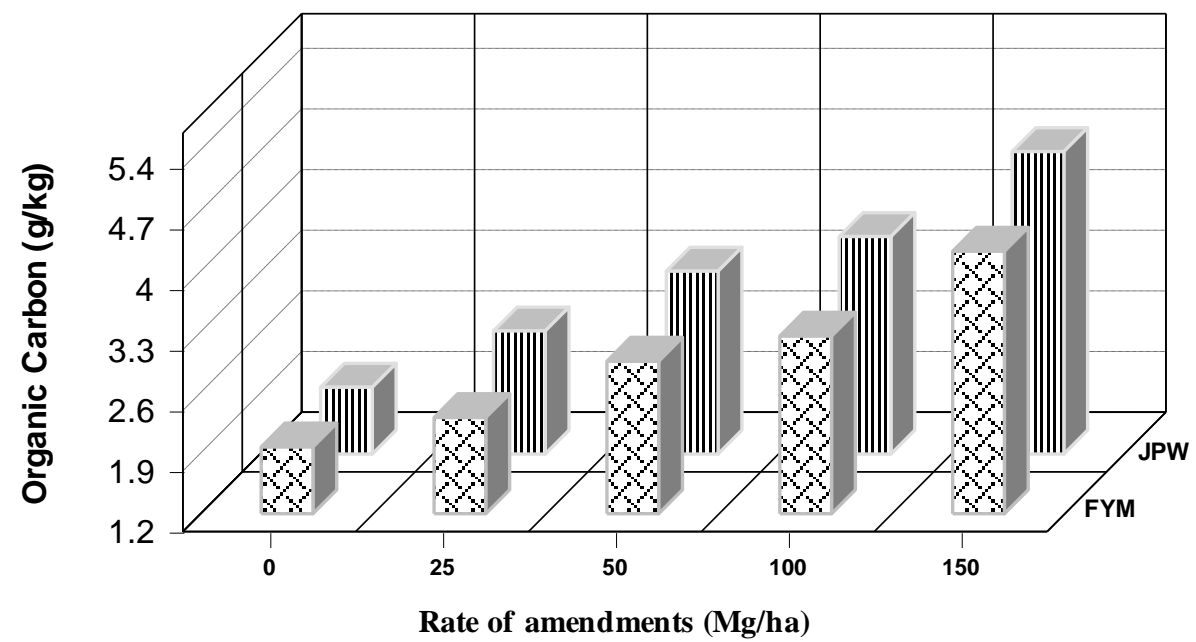

Fig. 3 Effect of JPW and FYM rates on soil OC 


\section{Soil Physical Properties:}

\section{Bulk Density:}

Soil bulk density decreased with application of JPW or FYM is shown in Table 3 and Fig. 4.

Table 3: Effect of JPW and FYM rates on soil physical properties.

\begin{tabular}{|c|c|c|c|c|c|}
\hline treatments & $\begin{array}{c}\text { Rate } \\
\left(\mathrm{Mg} \mathrm{ha}^{-1}\right)\end{array}$ & $\begin{array}{c}\text { Bulk } \\
\text { density } \\
\left(\mathrm{Mg} \mathrm{m}^{-3}\right)\end{array}$ & $\begin{array}{l}\text { Penetration } \\
\text { resistance } \\
\text { (Kpa) }\end{array}$ & $\underset{(\%)}{\operatorname{MWHC}}$ & $\begin{array}{c}\mathbf{H C} \\
\left(\mathrm{cm} \mathrm{h}^{-1}\right)\end{array}$ \\
\hline Control & $\overline{\mathbf{0}}$ & 1.66 & 9.41 & $\overline{4.78}$ & 24.13 \\
\hline \multirow{4}{*}{ 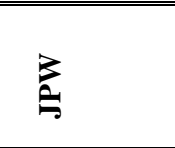 } & 25 & 1.53 & 8.15 & 8.62 & 19.21 \\
\hline & 50 & 1.49 & 7.52 & 9.47 & 17.93 \\
\hline & 100 & 1.43 & 7.01 & 10.89 & 16.35 \\
\hline & 150 & 1.35 & 6.61 & 12.15 & 14.65 \\
\hline \multirow{4}{*}{$\sum_{i}$} & 25 & 1.58 & 8.37 & 7.44 & 20.78 \\
\hline & 50 & 1.55 & 7.83 & 8.92 & 19.51 \\
\hline & 100 & 1.47 & 7.33 & 10.27 & 18.81 \\
\hline & 150 & 1.39 & 6.86 & 11.13 & 16.69 \\
\hline \multicolumn{2}{|l|}{$L S D_{(0.05)}$} & 0.017 & 0.15 & 0.17 & 0.26 \\
\hline
\end{tabular}

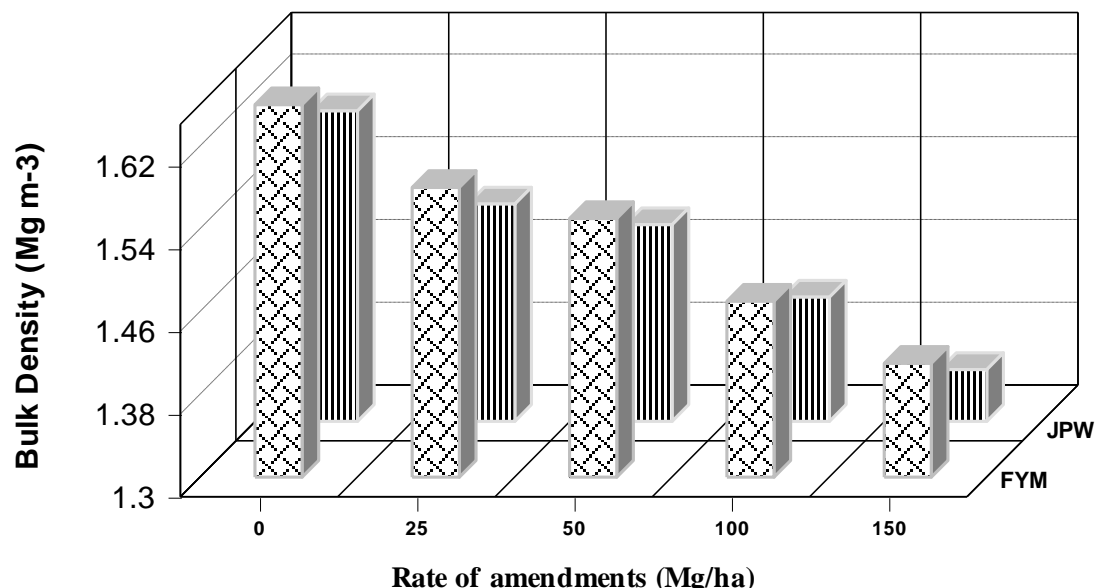

Fig. 4: Effect of JPW and FYM rates on soil bulk density

Values of bulk densities are decreased with increasing application rates of either JPW or FYM. The relative reductions in soil bulk density reach $8,10,14$ and $19 \%$ on an average base due to the increase in JPW rates $\left(25,50,100\right.$, and $\left.150 \mathrm{Mg} \mathrm{ha}^{-1}\right)$, respectively, while, they reach 5,7 , 11 and $16 \%$ on an average base due to the increase in FYM rates $(25,50$, 100 , and $150 \mathrm{Mg} \mathrm{ha}^{-1}$ ), respectively. This clearly shows the adverse effect of increasing application rates of either JPW or FYM on soil bulk density. Khan, et al., (2019) found that the applied farmyard manure decreased the bulk density of soil.

\section{Penetration Resistance:}

The soil penetration resistance is an indicator for the soil physical properties, as the decrease in penetration resistance allows the plant roots 
for easy penetration in the soil. As shown in Table 3 and Fig. 5 a decrease in soil penetration resistance is accompanied by an increase in the rates of either JPW or FYM. Significant differences in soil penetration resistance are obtained between pomegranate waste or FYM.

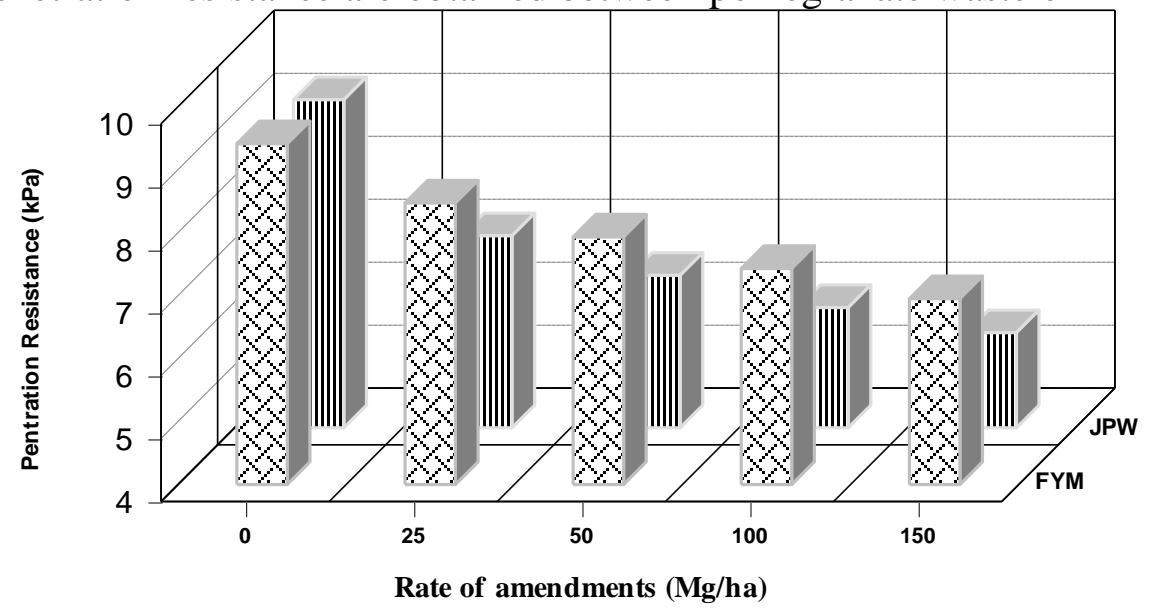

Fig. 5: Effects of JPW and FYM applications on soil penetration resistance.

Maximum Water Holding Capacity (MWHC):

Incorporating of either JPW or FYM with surface soil could enhance soil physical properties. Data in Table 3 and Fig. 6 clearly appear that the effect was increased with increasing the application rates of JPW or FYM. The relative increases in the MWHC reach 45, 50, 56, and 61\% for JPW additions of $25,50,100$, and $150 \mathrm{Mg} \mathrm{ha}^{-1}$, respectively. While, the relative increment reach $36,46,53$, and $57 \%$ for FYM, respectively.

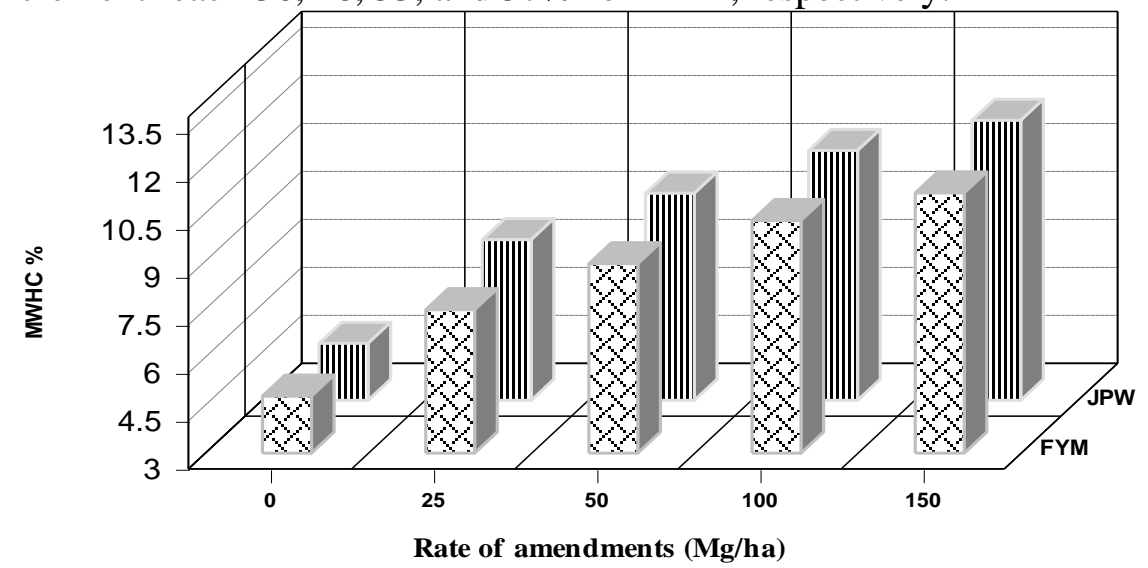

Fig. 6: Effects of JPW and FYM applications on soil maximum water holding capacity. 


\section{Hydraulic Conductivity (HC):}

Data presented in Table 3 and Fig. 7 show a decrease in hydraulic conductivity with the increase of amendments application rate.

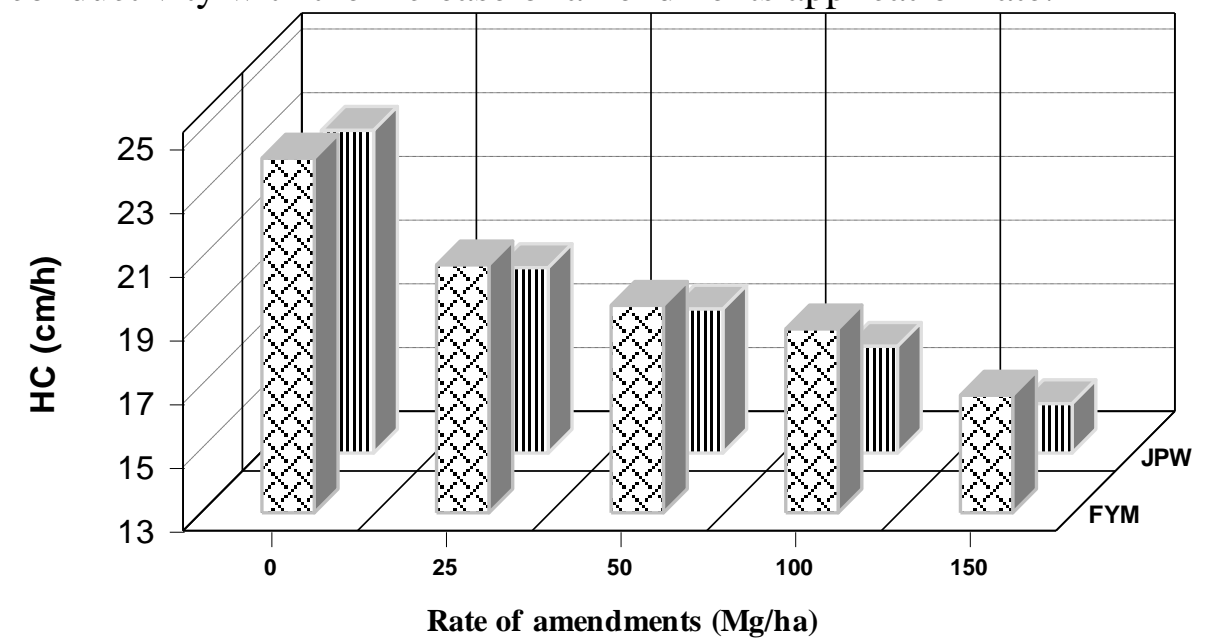

Fig. 7: Effects of JPW and FYM applications on soil hydraulic conductivity.

Relative decreases in hydraulic conductivity reach $20,26,32$, and $39 \%$ on an average due to the increase in juice pomegranate wastes application rates from 0 to $25,50,100$, and $150 \mathrm{Mg} \mathrm{ha}^{-1}$, respectively. While, relative decreases in hydraulic conductivity reach $14,19,22$, and $31 \%$ on an average base due to the increase in FYM application rates from 0 to $25,50,100$, and $150 \mathrm{Mg} \mathrm{ha}^{-1}$, respectively.

\section{Mineral Composition in wheat grains:}

Data in Table 4 show the changes in the concentrations of some nutritive elements with increasing the application rates of JPW and FYM rates.

\section{$N$ content in wheat grains:}

Table 4 and Fig. 8 show that the values of $\mathrm{N}$ content in wheat grain range from 13.68 to $27.93 \mathrm{mg} \mathrm{kg}^{-1}$ and from 13.68 to $25.57 \mathrm{mg} \mathrm{kg}^{-1}$ due to increasing the application rates of JPW and FYM respectively, N content in wheat grain is affected by either JPW and FYM application rates. The highest increment in N content was achieved JPW and FYM with higher application rates of $150 \mathrm{Mg} \mathrm{ha}^{-1}$. The response to $\mathrm{N}$ is significant and linear relationship between $\mathrm{N}$ content of either JPW or FYM rate. The higher $\mathrm{N}$ content in wheat grain due to JPW and FYM application rates may be due to the higher initial content of $\mathrm{N}$ in such 
materials (Table 1). Also, the positive effect of adding JPW and FYM in enhancing soil physical and chemical properties of studied soil (Table 2 and 3) reflected in higher plant growth and $\mathrm{N}$ uptake.

Table 4: $N$, $P$, and $K$ contents in wheat grains as effect by the application rates of JPW and FYM.

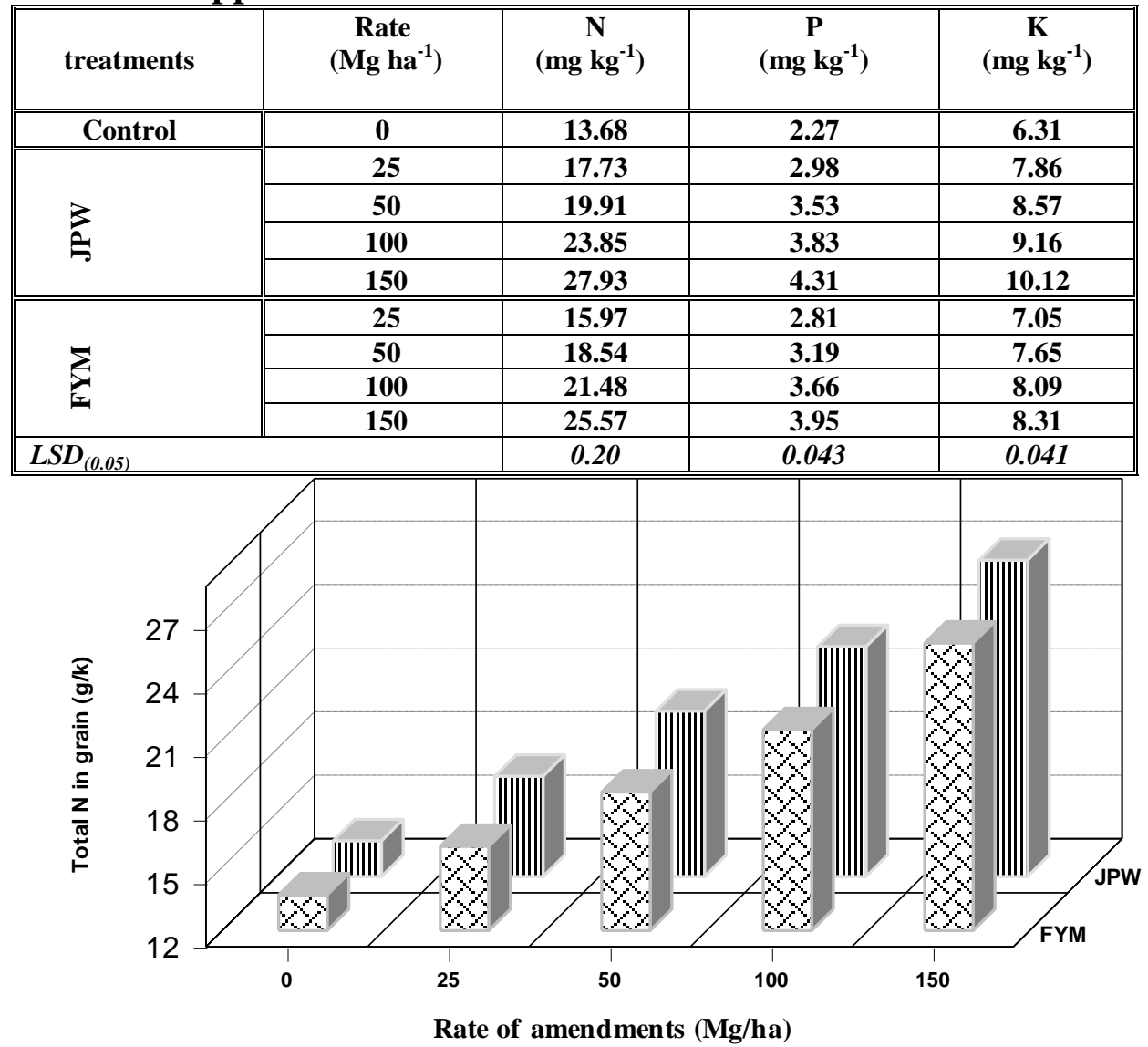

Fig. 8: Effect of application rates of JPW and FYM rates on $N$ content in wheat grains.

\section{$P$ content in wheat grains:}

Data in Table 4 and Fig. 9 show that $\mathrm{P}$ content in treated wheat was $2.27 \mathrm{mg} \mathrm{kg}^{-1} \mathrm{JPW}$ caused increases of up to $90 \%$, while, FYM causes increases of up to $61 \%$ increased rate was associated with increased P content, JPW gave higher P content than FYM. The higher P content in wheat grain due to JPW and FYM may be referring to the higher $\mathrm{P}$ content in such materials (Table 1). Beside their effect in 
enhancing soil physical and chemical properties (Table 2 and 3) which gave the chance to a better plant growth and hence increasing $\mathrm{P}$ uptake.

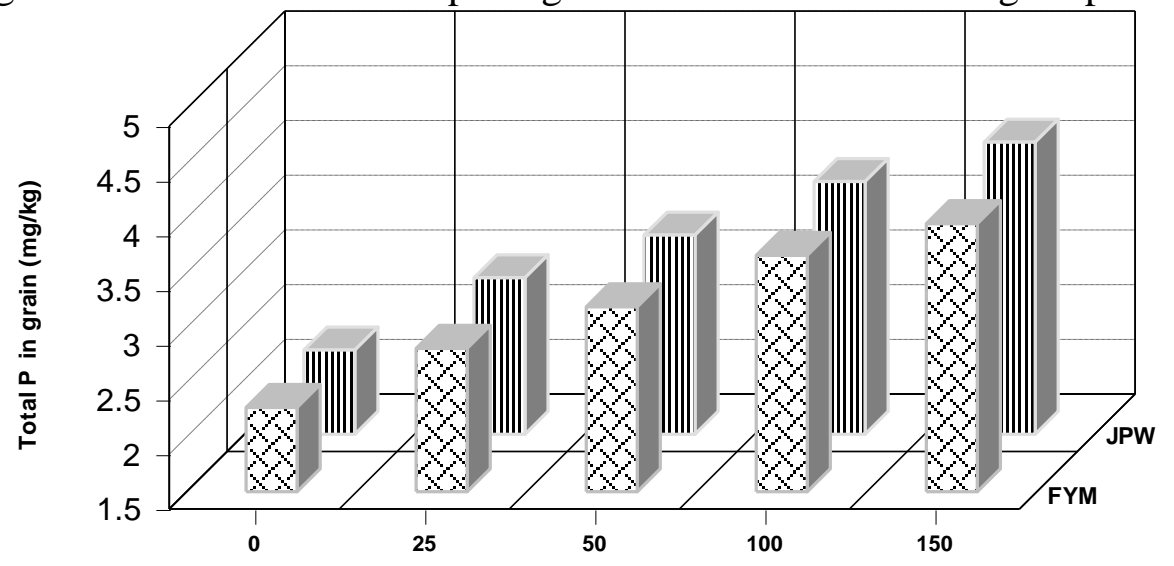

Rate of amendments $(\mathrm{Mg} / \mathrm{ha})$

Fig. 9: Effect of application rates of JPW and FYM rates on $P$ content in wheat grain.

Potassium content in wheat grains:

Table 4 and Figure 10 show that $\mathrm{K}$ content in the control treatment $6.31 \mathrm{mg} \mathrm{kg}^{-1}$. While it increased over the control by $24.6,35.8,45.2$ and $60.4 \%$ due to treating the soil with JPW at the rates of $25,50,100$ and $150 \mathrm{Mg} \mathrm{ha}^{-1}$ respectively. The respective increment reached to $11.7,21.2$, 28.2 and $31.7 \%$ respectively due to FYM application rates. It is obvious that the differences are significant in K content between JPW and FYM application rates (table 4).

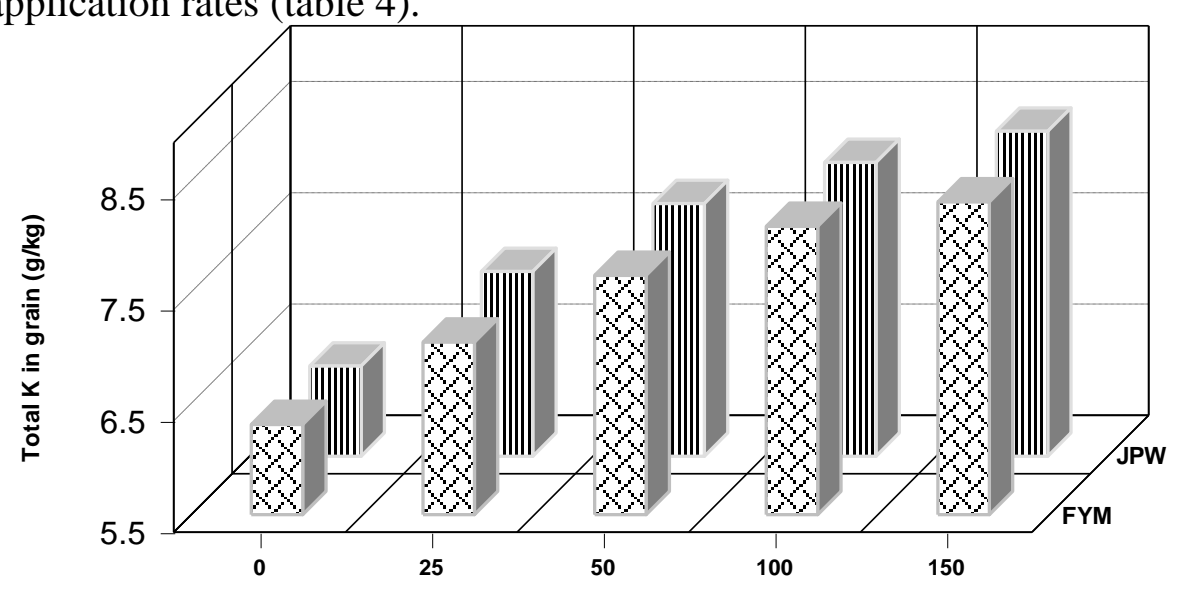

Fig. 10: Effect of application rates of JPW and FYM rates on $K$ content in wheat grain. 
The higher $\mathrm{K}$ content in wheat grains due to JPW and FYM application may be resulted from the higher content of $\mathrm{K}$ in such materials (Table 1), beside their effect in enhancing soil physical and chemical properties (Table 2 and 3) Which reflected in a batter plant growth and higher K uptake.

\section{Wheat grain Yield:}

Data in Table 5 represent the response of wheat grain yield due to the application of JPW and FYM. The applications of either juice pomegranate wastes or FYM rates at all four rates $(25,50,100$ and 150 $\mathrm{Mg} \mathrm{ha}^{-1}$ ) significantly increase the wheat grain yield. Maximum yield is achieved with the application of $150 \mathrm{Mg} \mathrm{ha}^{-1}$ of juice pomegranate wastes. These results are in agreement with those obtained by Abdel-Aal (2015) who found that application of FYM resulted the high wheat grain yields as well as $\mathrm{N}, \mathrm{P}, \mathrm{K}, \mathrm{Fe}, \mathrm{Mn}$ and $\mathrm{Zn}$ contents in grains.

Table 5: Wheat grain yield as affected by application of JPW and FYM.

\begin{tabular}{|c|c|c|}
\hline Treatments & $\begin{array}{c}\text { Rate } \\
\left(\mathrm{Mg} \mathrm{ha}^{-1}\right)\end{array}$ & $\begin{array}{c}\text { grain yield } \\
\left(\mathrm{Mg} \mathrm{ha}^{-1}\right)\end{array}$ \\
\hline Control & $\overline{0}$ & 1.79 \\
\hline \multirow{4}{*}{ 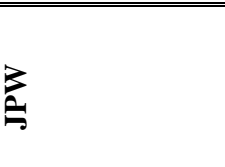 } & 25 & 2.91 \\
\hline & 50 & 3.68 \\
\hline & 100 & 4.77 \\
\hline & 150 & 5.74 \\
\hline \multirow{4}{*}{$\sum_{I}$} & 25 & 2.44 \\
\hline & 50 & 3.29 \\
\hline & 100 & 4.07 \\
\hline & 150 & 4.99 \\
\hline$\overline{L S D_{(0.05)}}$ & \multicolumn{2}{|c|}{0.18} \\
\hline
\end{tabular}

Data presented in Table 5 and Fig. 11 show that the difference between JPW and FYM rates is significant and increases with increasing application rates. Moreover, JPW increased wheat grain yield by an average of $63,106,167$, and $221 \%$ relative to control with the application of $25,50,100$ and $150 \mathrm{Mg} \mathrm{ha}^{-1} \mathrm{JPW}$ respectively. While, the relative increment in wheat grain yield reached of $36,84,127$, and $179 \%$ with the application rates of FYM 25, 50, 100 and $150 \mathrm{Mg} \mathrm{ha}^{-1}$ respectively.

The favorable effect of JPW and FYM an increasing wheat grain yield is a function of enhancing soil physical and chemical properties of the studied soil (i.e. increasing water holding capacity, reducing both soil bulk density and penetration resistance (Table 3) as well as reducing soil 
salinity (Table 2). Beside higher initial contents of N, P, K, Fe, Mn, Zn and $\mathrm{Cu}$ (Table 1). This may be reflected in a better condition for plant growth and high grain yield.

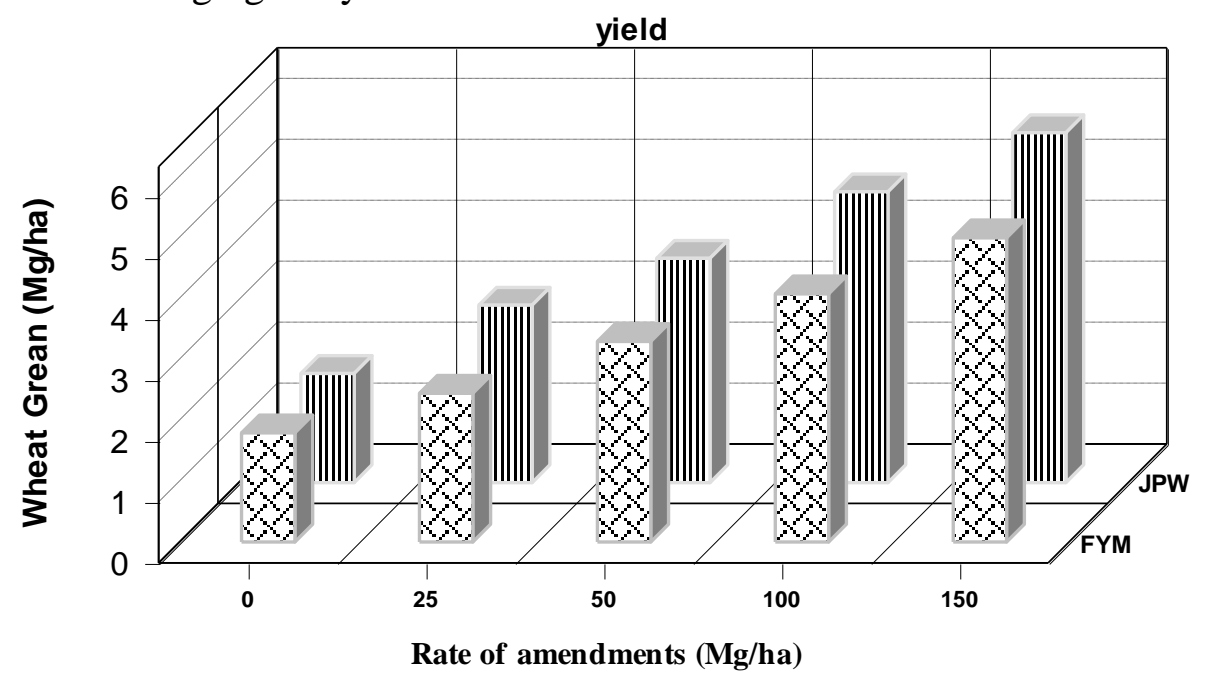

Fig. 11: Effect of JPW and FYM applications on wheat grain yield.

The relationships between either juice pomegranate wastes (JPW) or FYM rates and wheat grain production were fitted using best fitting equation in Table 6.

Table 6: Regression equations and correlation coefficients (r) between either JPW or FYM rates and yield of wheat grain.

\begin{tabular}{|c|c|c|}
\hline Type & Equation & $\mathbf{r}$ \\
\hline \multirow{2}{*}{ Quadratic } & Grain $=1.87+0.099 \times$ JPW rate $-5.8957 \mathrm{e}^{-4} \times \mathrm{JPW}$ ratre $^{2}$ & $0.99^{* *}$ \\
\hline & Grain $=1.802+0.074 \times$ FYM rate $-3.5255 \mathrm{e}^{-4} \times$ FYM rate $^{2}$ & $0.99^{* *}$ \\
\hline \multirow{2}{*}{ Square-root } & Grain $=1.559+0.511 \times J P W$ rate $^{1 / 2}$ & $0.98^{* *}$ \\
\hline & Grain $=1.514+0.415 \times$ FYM rate re $^{1 / 2}$ & $0.97^{* *}$ \\
\hline \multirow{2}{*}{ Inverse } & Grain $=5.743-30.646 / \mathrm{JPW}$ rate & $0.92^{* * *}$ \\
\hline & Grain $=5.007-27.323 /$ FYM rate & $0.93^{* *}$ \\
\hline \multirow{2}{*}{ Power } & Grain $=1.209 \times \mathrm{JPW}$ rate $^{0.376}$ & $0.98^{* *}$ \\
\hline & Grain $=1.008 \times$ FYM rate re.387$^{0.7}$ & $0.98^{* * *}$ \\
\hline \multirow{2}{*}{ Exponential } & Grain $=2.204 \times \mathrm{e}^{(0.01778 \times \mathrm{JPW} \text { rate })}$ & $0.94^{* *}$ \\
\hline & Grain $=2.038 \times \mathrm{e}^{(0.0162 \times \text { FYM rate })}$ & $0.96 *$ \\
\hline \multirow{2}{*}{ Logarithmic } & Grain = -0.801+1.552 $x \ln (\mathrm{JPW}$ rate $)$ & $0.97^{* * *}$ \\
\hline & Grain $=-0.771 \quad-0.771 x \ln ($ FYM rate $)$ & $0.98^{* *}$ \\
\hline \multirow{2}{*}{ Liner } & Grain $=-31.871+15.318 \mathrm{JPW}$ rate & $0.96^{2 * 3}$ \\
\hline & Grain $=-35.893+18.665$ FYM rate & $0.98^{* * *}$ \\
\hline
\end{tabular}

**: Significant at $1 \%$

Statistical analysis showed that a quadratic function fitted the relationship between either JPW or FYM rates and yield of wheat grain ( $r$ $=0.99^{* *}$ and $0.99^{* *}$, respectively) as compared to the other equations. 
The correlation obtained for the quadratic relationship between either JPW or FYM rates and grain wheat yield is as follows: Grain Wheat $=1.87+0.099 \times \mathrm{JPW}$ rate $-5.8957 \mathrm{e}^{-4} \times \mathrm{JPW}$ rates $^{2}$, Grain Wheat $=1.802+0.074 \times$ FYM rate $-3.5255 \mathrm{e}^{-4} \times$ FYM rates $^{2}$, [2]

This indicates that yield increase is attributable to amendment additions.

Differential's method of quadratic regression (equation [1] and [2]) can be used to find the predicted critical rate of amendment, as critical level represent the rate where further change in the yield results in a reduction in yield.

In this respect, the differential quadratic regression (equations [1] and [2]) are as follows:

$$
\begin{aligned}
& \mathrm{dy} / \mathrm{dx}=0.099-0.001179 \mathrm{JPW} \text { rate } \\
& \mathrm{dy} / \mathrm{dx}=0.074-0.0007051 \mathrm{FYM} \text { rate }
\end{aligned}
$$

The value for critical level reached $202 \mathrm{Mg} \mathrm{ha}^{-1}$ and $252 \mathrm{Mg} \mathrm{ha}^{-1}$ for JPW and FYM respectively. Increasing this rate of addition will decline the yield. Can be concluded that grain yield would increase up to 14.5 and $13.6 \mathrm{Mg} \mathrm{ha}^{-1}$ by JPW or FYM treatment, respectively, and then decreases with further increase in rate.

A highly significant was found between grain wheat yield amended by JPW or FYM rates and either $\mathrm{pH}, \mathrm{EC}, \mathrm{OC}$, bulk density, penetration resistance, hydraulic conductivity or maximum water holding capacity (MWHC), respectively.

Table 7: Correlation coefficient between wheat grain yield amended

\begin{tabular}{|c|c|c|}
\hline \multirow{2}{*}{ Soil Property } & \multicolumn{2}{|c|}{ Wheat grain amendments by } \\
\hline & JPW & FYM \\
\hline pH & $-0.97^{* *}$ & $-0.98^{* *}$ \\
\hline EC & $-0.99^{* *}$ & $-0.98^{* * *}$ \\
\hline OC & $0.99^{* * *}$ & $0.98^{* * *}$ \\
\hline Bd & $-0.98^{* * *}$ & $-0.98^{* *}$ \\
\hline HC & $-0.91^{* *}$ & $-0.97^{* *}$ \\
\hline penetration & $-0.96^{* *}$ & $-0.95^{* * *}$ \\
\hline MWHC & $0.96^{* *}$ & 0.96 ** \\
\hline
\end{tabular}
of JPW or FYM rates and some soil properties

**: Significant at $1 \%$

Also, the multiple regression relating the grain wheat yield to some soil properties and either JPW or FYM amending rates yields the following equation [3] and [4], respectively:

Grain yield $=-1.190+2.794 \mathrm{OC}-2.480 \mathrm{pH}+4.873 \mathrm{EC}-10.964$ Bulk density -2.831 Penetration resistance +0.989 Hydraulic conductivity +0.298 Maximum water holding capacity + $0.061 \mathrm{JPW}$ rates 
Grain yield $=-38.784+0.838 \mathrm{OC}+4.755 \mathrm{pH}+0.246 \mathrm{EC}-2.078$ Bulk density -0.440 Penetration resistance +0.989 Hydraulic conductivity +0.231 Maximum water holding capacity + 0.024 FYM rates

The multiple correlation was highly significant $\left(\mathrm{r}=0.99^{* *}\right)$ indicating that $96.04 \%$ of the variations in grain wheat yield could be attributed to the variation in soil $\mathrm{OC}, \mathrm{pH}, \mathrm{CE}$, bulk density, penetration resistance, hydraulic conductivity, maximum water holding capacity and either JPW or FYM amending rate.

Agronomic efficiency index (AEI):

Agronomic efficiency index (AEI) of JPW and FYM was calculated from the grain yield from regression relationship as follows:

$$
\mathrm{AEI}=\left(G Y_{F x}-G Y_{F 0}\right) / F X
$$

Where: $\boldsymbol{G Y}$ is the grain yield production and $\boldsymbol{F}$ is the rate of either JPW or FYM distributed at 0 (control) and rate $\boldsymbol{x}$. Agronomic efficiency index of JPW or FYM rates (i.e. the grain yield per unit of wastes) shows marked differences in relation to amendments rates (Table 8 and Fig. 12). The value of agronomic efficiency index decreases with increasing the rate of wastes.

Table 8: Agronomic efficiency index for wheat grain yield as affected by added JPW and FYM rates.

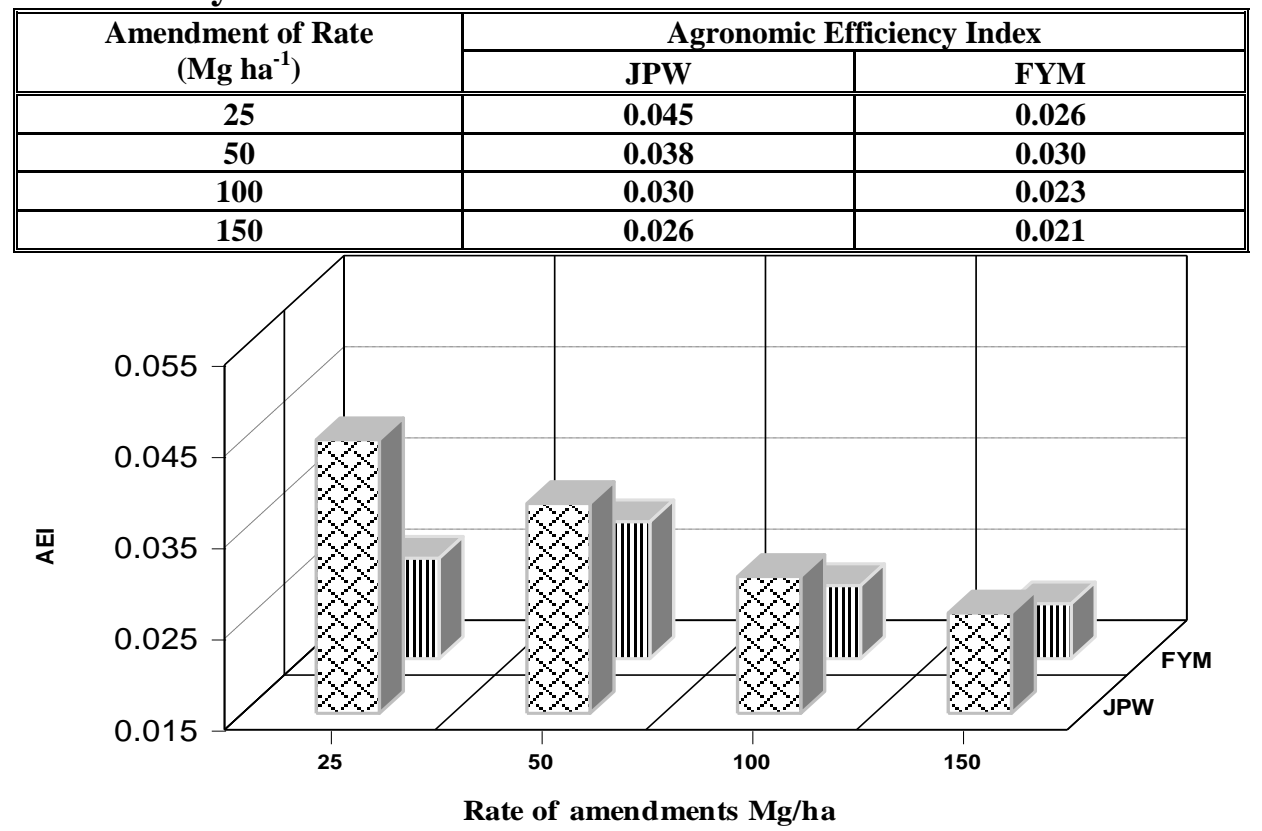

Fig. 12: Effect of application JPW and FYM rates on agronomic efficiency index. 


\section{Economical Grain Yield of Wheat:}

To lay out amending policy of any crop, the economical aspect should be considered. Due to the increase of amendment rate prices, the yield per unit amendment rate should be overlooked, as the economical yield is not necessary the highest.

Data in Table 9 indicate that the yield per unit $\left(1 \mathrm{Mg} \mathrm{ha}^{-1}\right)$ amendment rate is the highest at the rates of 10 and $20 \mathrm{t} / \mathrm{fed}$. of amendment; as the increase for the mentioned rate ranges.

The highest increase for each excess unit $\left(1 \mathrm{Mg} \mathrm{ha}^{-1}\right)$ of amendment rate is noticed in the case of juice pomegranate waste amendment followed by FYM for the two rates of 25 and $50 \mathrm{Mg} \mathrm{ha}^{-1}$ of amendment rates, where the yield is found to be 0.045 and $0.034 \mathrm{Mg} / \mathrm{unit}$ amendment, respectively.

From the environmental point of view, the problem of pomegranate waste and FYM accumulations can be partially solved and its pollution effect will be diminished to a certain level in order to improve the surrounding environment.

Table 9: Rate of increase in grain yield $\left(\mathrm{Mg} \mathrm{ha}^{-1}\right)$ of wheat per unit increase of amendment rate

\begin{tabular}{|c|c|c|c|}
\hline $\begin{array}{c}\text { Rate of added } \\
\text { amendment }\left(\mathrm{Mg} \mathrm{ha}^{-1}\right)\end{array}$ & $\begin{array}{c}\text { Type of } \\
\text { amendment }\end{array}$ & $\begin{array}{c}\begin{array}{c}\text { Yield per unit } \\
\text { amendment }\end{array} \\
\end{array}$ & $\begin{array}{c}\text { Increase of each excess } \\
\text { unit }{ }^{*} \text { amendment }\end{array}$ \\
\hline 0 & $\begin{array}{l}\text { JPW } \\
\text { FYM }\end{array}$ & $\begin{array}{l}- \\
-\end{array}$ & $\begin{array}{l}- \\
-\end{array}$ \\
\hline 25 & $\begin{array}{l}\text { JPW } \\
\text { FYM } \\
\end{array}$ & $\begin{array}{l}0.045 \\
0.026 \\
\end{array}$ & $\begin{array}{l}0.045 \\
0.026 \\
\end{array}$ \\
\hline 50 & $\begin{array}{l}\text { JPW } \\
\text { FYM } \\
\end{array}$ & \begin{tabular}{l|l|}
$\mathbf{0 . 0 3 8}$ \\
$\mathbf{0 . 0 3 0}$ \\
\end{tabular} & \begin{tabular}{ll|}
0.031 \\
0.034 \\
\end{tabular} \\
\hline 100 & $\begin{array}{l}\text { JPW } \\
\text { FYM } \\
\end{array}$ & $\begin{array}{l}\mathbf{0 . 0 3 0} \\
\mathbf{0 . 0 2 3} \\
\end{array}$ & $\begin{array}{l}0.022 \\
0.016 \\
\end{array}$ \\
\hline 150 & $\begin{array}{l}\text { JPW } \\
\text { FYM }\end{array}$ & $\begin{array}{l}0.026 \\
0.021 \\
\end{array}$ & $\begin{array}{l}0.019 \\
0.018\end{array}$ \\
\hline $\begin{array}{l}202^{* * *} \\
252^{* * *}\end{array}$ & $\begin{array}{l}\text { JPW } \\
\text { FYM }\end{array}$ & $\begin{array}{l}\mathbf{0 . 0 2 1} \\
\mathbf{0 . 0 1 5}\end{array}$ & $\begin{array}{l}0.006 \\
0.017\end{array}$ \\
\hline
\end{tabular}

*: $1 \mathrm{Mg}$ of amendment

**: critical level of amendment

\section{REFERENCES}

Abdel-Aal, M.H. (2015). Responding of some physical and chemical properties of deteriorated soil at el-fayoum oasis and wheat yield to tillage and amendments. J.Soil Sci. Agric. Eng., Mansoura Univ., 6 (4): 483 - 498.

Abdel-Salam, F.F. ; G.M. Yehia and E.M. El-Zalaki (2018). Characterization of wastes from pomegranate (Punica granatum 
L.) juice and its use as a functional drink. Egypt. J. Fd. Sci., 46: 91- 100.

Abou Yuossef, M.F. ; M.H. Aly and A.S. EL Kot (2007). Evaluation of sugarcane filter mud as soil conditioner under saline water irrigation. Annals Agric. Sci., Moshtohor, 45: 469-484.

Adulse, R.N. and N.B. Patil (1995). Pomegranate; production, composition, storage and processing" In "Hand book of Fruit Science and Technology". Salunkhe, D.K. and Kadom, S.S. (eds). Marcel Dekker, Inc. NU., 455-464.

ASAE Standards, (1993). S313.2 Soil Cone Penetromater, 40 ${ }^{\text {th }}$ Edi. ASAE, St. Joseph, MI.

Blake, G.R. (1986). Bulk density. 374 - 390. In "Page, et. el. (eds.). Methods of soil analysis, Part I. Physical and Mineralogical Methods, Am. Soc. Agron. Inc. Medison, WI. USA.

Bulluck, L.R.; M. Brosius; G.K. Evanylo and J.B. Ristaino (2002). Organic and synthetic fertility amendments influence soil microbial, physical and chemical properties in organic and conventional farms. Appl. Soil Ecol., 19: 147-160.

Divina, C.C. (2016). Fruit wastes for benefits of plants and animals. Int. J. of Agric. Tech., 12:1535-1545

Dumlu, M.U. and E. Gurkan (2007). Elemental and nutritional analysis of Punica granatum L. from Turkey. J. Med. Fd., 10: 392-395.

Fire, E.A.; K.C. Peyer and F.A. Schutz (1964). Determination of phosphorus by ascorbic acid. Schw. Landwirtschaft Forschung, 3: 318-328.

Golukci, M. (2014). The effects of drying methods, packaging atmosphere and storage time on dried pomegranate arils quality. J. Agric. Sci., 18: 206-219.

Hasnaoui, N. ; B. Wathelet and A. Jimenez-Araujo (2014). Valorization of pomegranate peel from 12 cultivars: Dietary fiber composition antioxidant capacity and functional properties. Fd. Chem., 160: 196-203.

Jariwala, J.H. and S.S. Huma (2016). Study on use of fruit peels powder as a fertilizer. National Conference on Recent Advances in Environmental Sciences and Engineering Technologies, JIET, Jodhpur, Rajasthan (November 2016) 334 - 337.

Jackson, A.L. (1973). Soil chemical analysis. Pub. by Auther, Dept. of Soils, Univ. of Wisc. Madison, Wisc., U.S.A. 
Khan, N.I. ; A.U. Malik ; F. Umer and M.I. Bodla (2019). Effect of tillage and farm yard manure on physical properties of soil. Intl. Res. J. Pl. Sci., 1 (4):75-82.

Klute, A. (1986). Laboratory measurment of hydraulic conductivity of saturated soil. pp 210 -220. In "Page, et. el. (eds.). Methods of Soil Analysis, Part I. Physical and Mineralogical Methods, Am. Soc. Agron. Inc. Medison. WI. USA.

Phillips, R.E. ; R.L. Blevins ; G.W. Thomas ; W.W. Frye and S.H. Phillips (1980). No-tillage agriculture. Science, 208: 1108 -1113.

Richards, L.A. (1954). Diagnosis and improvement of saline and alkali soils U. S. Salinity Laboratory Staff. Agriculture Hand book No. 60. Printing office, Washington, USA.

Stolte, J. ; G.J. Veerman and M.C.S. Wopereis (1992). Manual soil physical measurements, version 2.0. Technisch Document/ Technical Document 2, DLO Winand String Centre, Wageningen, The Netherlands.

Yassen, A.A. ; S.M. Khalid and S.M. Zaghloul (2010). Response of wheat to different rates and ratios of organic residues on yield and chemical composition under two types of soil. J. A. Sci., 6: 858-864.

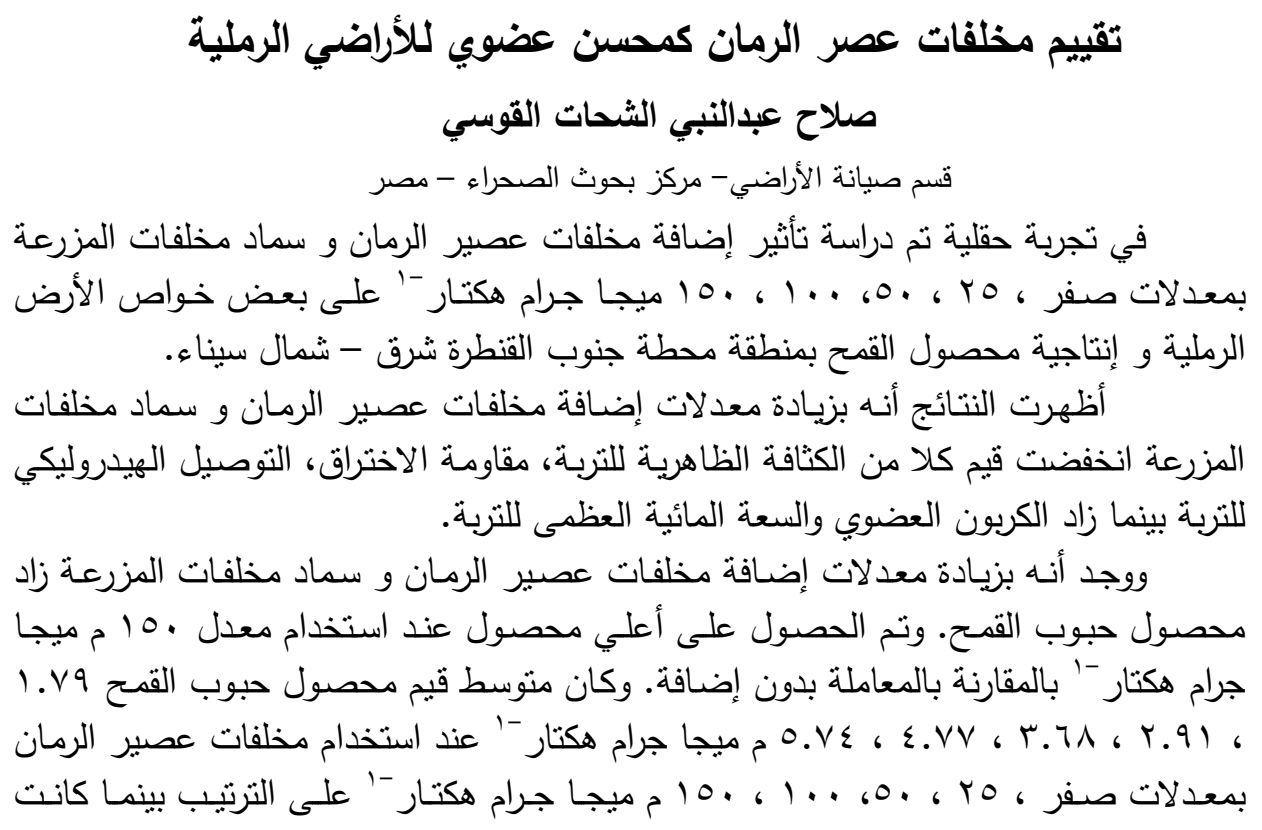




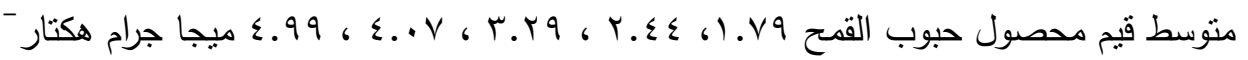

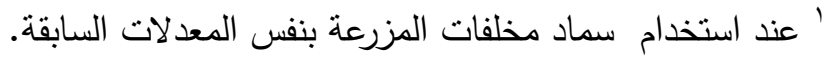

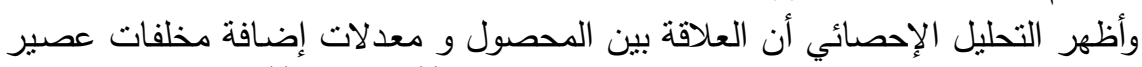

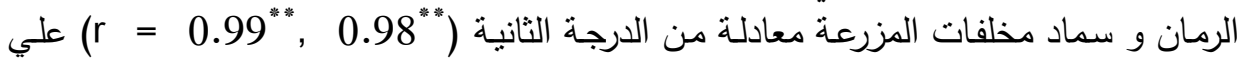

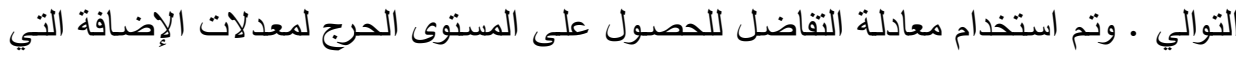

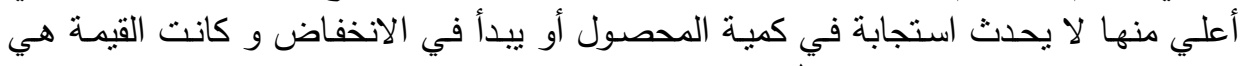

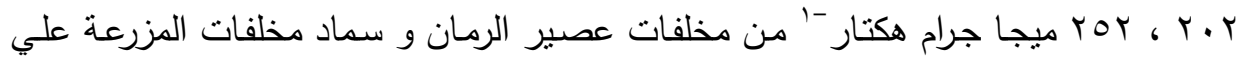
التوالي. وتدل النتائج أن استخدام مخلفات عصير الرمان تعتبر مصدر للمواد المحسنة لخواص التربة الرملية وإنتاجيتها. 